\title{
PENDAFTARAN SUARA SEBAGAI MEREK NON TRADISIONAL BERDASARKAN UNDANG - UNDANG NOMOR 20 TAHUN 2016 TENTANG MEREK
}

\author{
Penulis: \\ Ni Putu Winda Pramesti Dewi ${ }^{* *}$ \\ Ida Ayu Sukihana*** \\ Program Kekhususan Hukum Bisnis Fakultas Hukum \\ Universitas Udayana
}

\begin{abstract}
ABSTRAK:
Suara menjadi tanda pembeda yang potensial untuk didaftarkan sebagai merek. Dalam peraturan Undang - Undng Nomor 20 Tahun 2016 tentang Merek, suara termasuk tanda pembeda yang dilindungi. Namun mengenai pendaftarannya masih banyak kebingungan mengenai cara menampilkan suara dalam bentuk grafik dan bagaimana suara bisa didaftarkan sebagai merek.

Metode penulisan hukum normatif digunakan sebagai metode penulisan ini. Tujuan penulisan ini adalah untuk mengkaji mengenai pendaftaran suara sebagai merek berdasarkan ketentuan undang - undang di bidang Merek, serta mengkaji akibat hukum dari suatu merek tidak didaftarkan.

Hasil dari kajian penulisan ini yaitu pendaftaran suara berdasarkan ketentuan undang - undang merek bisa dilakukan dengan memenuhi persyaratan pendaftaran merek di Ditjen HKI, dimana khusus untuk pendaftaran suara harus dapat dipresentasikan secara grafis dengan melampirkan notasi dan rekaman suara. Sealnjutnya untuk merek yang tidak didaftarkan, akibat hukumnya dalah hak atas merek tersebut tidak akan diberikan oleh negara sehingga tidak akan mendapat perlindungan hukum.
\end{abstract}

Kata Kunci: Pendaftaran, Merek, Suara

ABSTRACT

\footnotetext{
*Tulisan ini merupakan tulisan ilmiah di luar ringkasan skripsi.

**Ni Putu Winda Pramesti Dewi adalah Mahasiswa Fakultas Hukum Universitas Udayana, windapramesti2112@gmail.com.

***Ida Ayu Sukihana adalah Dosen Fakultas Hukum Universitas Udayana, ayu_sukihana@yahoo.com.
} 
Sound is a potential differentiator to be registered as a trademark. In Law No. 20 of 2016 concerning Trademarks, the sound includes a distinguished sign that is protected. But regarding registration, there is still a lot of confusion about how to display sound in graphical form to be registered.

Therefore, the purpose of this pape is to review the registration of sound based on the regulation of trademarks, and to reviewing consequences of a trademark not registered. This writing uses normative law method of writing.

The result of this review is Sound registration based on trademark law can be done by fulfiling the trademark registration requirements at Intellectual Property Institution, whwre specifically for voice registration must be presented graphically by attaching notations and sound recordings. The legal consequence of a trademark that is not registered is that the state will not give rights to the trademark to trademark owener.

\section{Keyword: Registration, Trademark, Sound}

\section{PENDAHULUAN}

\section{$1.1 \quad$ Latar Belakang}

Dalam perkembangan ekonomi pada dewasa ini merek merupakan salah satu aset sangat berharga bagi perusahaan karena perusahaan menggunakan namanya sebagai merek dalam melaksanakan penjualan barang atau jasanya. Merek yang digunakan dan dipelihara dengan baik mengembangkan bisnis perusahaan secara lebih luas dan meningkatkan daya saing dengan perusahaan lain, baik dalam pasar nasional hingga internasional.

Pasal 1 angka 1 Undang - Undang nomor 20 Tahun 2016 tentang Merek (selanjutnya disebut dengan Undang - Undang Merek) menyatakan bahwa:

"Merek adalah tanda yang dapat ditampilkan secara grafis berupa gambar, logo, nama, kata, huruf, angka, susunan 
warna, dalam bentuk 2 (dua) dimensi dan/atau 3 (tiga) dimensi, suara, hologram, atau kombinasi dari dua atau lebih unsur tersebut untuk membedakan barang dan atau jasa yang diproduksi oleh orang atau badan hukum dalam kegiatan perdagangan barang dan/ atau jasa."

OK. Saidin menjelaskan merek adalah suatu tanda yang mempunyai daya beda produk yang dikeluarkan oleh perusahaan berbeda dengan yang dikeluarkan oleh perusahaan lain. ${ }^{1}$

Daya pembeda artinya yaitu tanda yang dipakai memiliki kemampuan guna membedakan hasil produk perusahaan satu dengan perusahaan lainnya. ${ }^{2}$

Salah satu tanda pembeda ini adalah suara (sound) dalam suatu produk. Dalam peraturan perundand - undangan di Inonesia suara sudah dapat didaftarkan sebagai merek berdasarkan ketentuan peraturan perundang - undangan. Suara menjadi tanda pembeda yang potensial untuk didaftarkan, terutama pada merek khusus yang memiliki tanda khas suara yang bernilai ekonomi tinggi. "Pendaftaran suara sebagai merek yang berhasil dilakukan adalah pendaftaran deru suara motor besar Harley Davidson sejak 1997."3

Suara termasuk kealam unsur baru, di luar unsur - unsur tradisional merek yang telah dikenal selama ini. "Unsur - unsur tersebut diantaranya:

1. "Single Color

2. Three - Dimensional Signs

a. shapes of product

\footnotetext{
1 Ibnu Munzir, dan Kadarudin, 2014, Perlindungan Hak Kekayaan Intelektual Terhadap Produk Indikasi Asal, Pustaka Pena Press, Makassar, h. 65.

${ }^{2}$ Dharmawan, N.K.S. \& Ketut, N, 2016, Hak Kekayaan Intelektual (HKI), Yogyakarta: Deepublish, h. 53.

${ }^{3}$ Jened, R., 2015, Hukum Merek (Trademark Law) dalam Era Gobalisasi dan Integrasi Ekonomi. Jakarta: Prenadamedia Group, h. 86.
} 


\section{b. packaging}

\section{Audible Signs}

4. Olfactory Signs, dan

5. Motion Signs"4

Unsur - unsur baru di luar unsur merek secara tradisional disebut dengan unsur merek nontradisional.

"Bagian merek nontradisional adalah merek berdasarkan penampilan (apperance). Suara, perasa, dan bentuk (shape). ${ }^{5}$

Indonesia sendiri berdasarkan Undang - Undang Merek baru mengatur tiga unsur merek nontradisional yaitu berupa tanda tanda 3 (tiga) dimensi, suara, dan hologram.

Peraturan perundang - undangan Merek di Indonesia menganut sistem konstitutif.6 "Sistem konstitutif yaitu hka atas merek didapatkan setelah pendaftaran, dimana pendaftar merek pertamalah berhak atas merek."7 Sehingga untuk medapatkan perlindungan hukum terhadap suatu merek harus dilakukan pendaftaran merek tersebut terlebih dahulu, dalam ketentuan hukum Merek positif di Indonesia saat ini telah mengatur suara sebagai merek yang dapat dilindungi. Dalam pembahasan tentang merek, biasanya diungkapkan bahwa pemilik merek yang dilindungi dapat mencegah penggunaaan merek tersebut oleh orang lain dan juga dapat melakukan perdagangan atas nilai

4 Utomo, T.S., 2010, Hak Kekayaan Intelektual (HKI) di Era Global Sebuah Kajian Kontemporer, Graha Ilmu, Yogyakarta, h.209.

5 Irianti, A.K, 2015, Perlindungan Hukum bagi Merek 3 Dimensi Menurut Undang - Undang No.15 Tahun 2001 tentang Merek (Tinjuauan Yuridis Putusan Mahkamah Agung Republik Indonesia No. 402 K/pdt.sus/2011). Kumpulan Jurnal Mahasiswa Fakultas Hukum, h.4.

${ }^{6}$ Sanjaya P.E.K., \& Rudy, D. G., 2018 Perlindungan Hukum terhadap Hak Merek Terkenal di Indonesia, Jurnal Fakultas Hukum Universitas Udayana, Kumpulan Jurnal Mahasiswa Fakultas Hukum, h. 6.

7 Dharmawan, N.K.S. \& Ketut, N, op. cit., h. 54. 
merek tersebut dengan jalan menjual atau memberi lisensi atas merek dagang tersebut. ${ }^{8}$

Namun sayangnya dalam pendaftarannya masih banyak kekeliruan dan kebingungan bagaimana suara yang merupakan tanda non visual dapat ditampilkan secara grafis dan di daftarkan sesuai dengan ketentuan Undang - Undang. Sehingga perlu kajian mengenai "PENDAFTARAN SUARA SEBAGAI MEREK NON TRADISIONAL BERDASARKAN DARI UNDANG - UNDANG NOMOR 20 TAHUN 2016 TENTANG MEREK"

\subsection{Rumusan Masalah}

1. Apakah suara dapat didaftarkan sebagai merek berdasarkan Undang - Undang no. 20 Tahun 2016?

2. Bagaimana akibat hukum suatu suara tidak didaftarkan sebagai merek?

\subsection{Tujuan Penulisan}

Penulisan ini memliki tujuan untuk mengetahui bagaimana prosedur pendaftaran suara sebagai merek berdasarkan Undang Undang no. 20 Tahun 2016 serta bagaimana akibat hukum jika suatu merek tidak didaftarkan.

\section{ISI MAKALAH}

\subsection{Metode Penelitian}

Metode penulisan hukum ini menggunakan metode penelitian hukum normatif. Metode ini disebut demikian sebab metode ini bertumpu pada kaidah - kaidah yang mengahruskan yang kepatuhannya dapat dipaksakan dengan menggunakan

8 Sardjono, A. 2010, Hak Kekayaan Intelektual \& Pengetahuan Tradisional, P.T. ALUMNI, Bandung h.456. 
kekuasaan negara (normatif). 9 Bahan hukum primer dimana merupakan bahan hukum yang mengikat ${ }^{10}$ berupa peraturan perundang - undangan. Bahan hukum sekunder yang digunakan dalam penelitian ini berupa buku - buku hukum merek. Penulisan jurnal ini menggunakan pendekatan undang - undang (statute approach) yaitu suatu pendekatan yang dilakukan dengan menelaah semua undang - undang dan regulasi yang bersangkut paut dengan isu hukum yang sedang ditangani. ${ }^{11}$

\subsection{Hasil dan Analisis}

\subsubsection{Pendaftaran Suara sebagai Merek di Indonesia}

Suara (sound) dalam kamus Besar Bahasa Indonesia diberi artikan sebagai:

1 bunyi binatang, alat perkakas, dsb.

2 bunyi yang dikeluarkan dari mulut manusia;

3 bunyi bahasa;

4 sesuatu yang dianggap pernyataan;

5 ucapan (perkataan);

Indonesia telah tergabung dalam Worl Trade Organisation (WTO), dimana dalam TRIP's Agreement, Annex 1C dari WTO secara tegas mengatur bahwa seluruh negara anggota wajib mentaati dan melaksanakan standar - standar universal TRIP'S secara full compliance dalam melindungi Hak Kekayaan Intelektual. ${ }^{12}$

Mengenai pendaftaran suara sebagai merek dalam dalam TRIP's Agreement, tidak ada keberatan untuk pendaftaran suara

9Irianto, S., \& Sidharta, B.A. 2009, Metode Penelitian Hukum: Konsilassi dan Refleksi, Jakarta: Yayasan Pustaka Obor Indonesia, h.143.

${ }^{10} \mathrm{~A}$. Amiruddin dan Zainal Asikin, loc. cit.

${ }^{11}$ Marzuki, P. M. 2005, Penelitian Hukum, Kencana, Jakarta, h. 93.

12 Dharmawan, N.K.S, 2011, Perlindungan Hukum Atas Karya Cipta Program Komputer di Indonesia (Studi Perbandingan dengan Negara Maju dan Negara Berkembang), Masalah - Masalah Hukum, h. 10. 
termasuk pendaftaran tanda non visual lainnya. Ketentuan "be visually preceptible" dalam TRIP's merupakan satunya masalah mungkin harus ditanggulangi oleh pendaftar merek dalam suatu negara yang menerapkann ketentuan ini. Presentasi grafis (graphical presentation) dari suara sebagai daya pembeda harus dapat dilakukan dengan objektif dan layak sehingga dapat dirasakan secara umum.

Peraturan Pasal 1 angka 1 Undang - Undang nomor 20 Tahun 2016 menyatakan; Merek adalah tanda yang dapat ditampilkan secara grafis. Kata "dapat ditampilkan secara grafis" menunjukan berlakunya ketentuan "visually perceptible". Ketentuan visual perceptible artinya pendaftaran suatu merek tersebut harus dapat digambarkan secara grafis dan objektif sehingga dapat diidentifikasikan oleh pihak ketiga.

"Dalam kasus pendaftaran suara sebagai merek, metode alternatif telah muncul untuk mempresentasikan suara dalam bentuk visual grafis dengan melakukan penggambaran suara dengan osilogram, spektrum suara, spektogram, dan sonogram. Representasi tersebut harus ditangani dengan hati - hati untuk memenuhi pendaftaran suara sebagai merek."13

Berdasarkan pasal 4 Undang - Undang Merek, pendaftaran suara sebagai merek di Indonesia bisa dilakukan dengan pengajuan permohonan pendaftaran Merek yang dilakukan oleh Pemohon/kuasanya ke mentri baik menggunakan media elektronik maupun media non elektronik.

${ }^{13}$ WIPO, 2009, Smell, Sound and Taste - Getting Sence of NonTraditional Marks, Serial Online Febuary, URL: https://www.wipo.int/wipo_magazine /en/2009/1/article_0003.html, diakses pada 25 Febuari 2019. 
Berkaitan dengan pendaftaran Merek berupa suara, pendaftarannya perlu melampirkan label merek yang dilampirkan berupa notasi dan rekaman suara. Setelah pengajuan permohonn, proses pendaftaran merek selanjutnya adalah pemeriksaan formalitas dan pemeriksaan substantif, apabila persyaratan permohonan pendaftaran dirasa belum memenuhi syarat kelengkapan, pemenuhan persyaratan tesebut terlama 2(dua) sampai 3(tiga) bulan. Waktu ini mulai dihitung sejak tanggal surat pemberitahuan kelengkapan persyaratan dikirim.

Jika telah disetujui, Ditjen HKI terhitung 10 hari setelahnya akan melakukan pengumuman merek secara resmi di berita merek.. Waktu untuk diumumkan adalah 3(tiga) bulan lamanya.

Dalam kurun waktu tersebut, pengajuan keberatan atas merek tersebut dapat diajukan dengan tertulis dan ditujukan ke Ditjen HKI. Terlama 2(dua) bulan dari tanggal diterimanya keberatan tersebut oleh Ditjen HKI, selanjutnya akan diadakan pemeriksaan kembali terhadap pemohon. Apabila tidak terdapat masalah lagi, penerbitkan dan peberian Sertifikat merek kepada pemohon/kuasanya dilakukan terlama 30 ( tiga puluh) hari tertanggal permohonan itu disetujui sebagai merek terdaftar oleh Ditjen HKI.

Sebagai tambahan, tidak bisa didaftarkannya suatu merek adalah karena permohonan merek tersebut tidak beritikad baik.

"Pemohon yang beritikad baik adalah pemohon yang mendaftarkan mereknya secara layak dan jujur tanpa ada niat apapun untuk membonceng, meniru atau menjiplak ketentuan merek pihak lain demi kepentingan usahanya yang berakibat kerugian pada pihak lain atau menimbulkan 
kondisi persaingan curangan, mengecoh, atau menyesatkan konsumen. ${ }^{14}$

\subsubsection{Akibat Hukum Suara yang Tidak Didaftarkan sebagai Merek}

Penanda dasar yang dikenal oleh konsumen untuk membedakan barang satu dengan lainnya dalam jenis yang sama dikenal dengan istilah merek. Menurut R. Soekardono dikutif dalam buku Perlindungan Hukum terhadap merek karya Hery Firmansyah, menyatakan bahwa "merek adalah suatu tanda, dimana menjadi pribadi sebuah barang atau jasa tertentu, dimana perlu memberikan tanda asalnya barang atau jasa tersebut guna menjamin kualitas atau mutu barang tersebut dengan barang barang sejenis yang dibuat atau diperniagakan sebagai perbandingan produk hasil badan - badan perusahaan yang satu dengan perusahaan lain." 15

Dalam sistem konstitutif pendaftaran merek akan memperoleh hak atas merek. Pada sistem konstitutif timbulnya hak merek baru akan terjadi apabila telah didaftarkan oleh si pemegang dimana sangat berbeda dengan sistem deklaratif yang bersifat lansung. ${ }^{16}$

Dalam menggunakan merek itu sendiri maupun dalam hal pemberian izin pihak lain menggunakan mereknya merupakan hak atas merek yang dimiliki oleh pemilik merek. Di samping itu, pencegahan penggunaan merek oleh orang yang tidak memiliki

14 Miru, A. (2005), Hukum Merek: Cara Mudah Mempelajari Undang Undang Merek, PT RajaGrafindo Persada, Jakarta, h. 14.

15 Fermansyah H., 2018, Perlindungan Hukum Terhadap Merek: Panduan Memahami Dasar Hukum Penggunaan dan Perlindungan Merek, Medpress, Yogyakarta, h. 29.

16 Megatri E. (2018) "Potensi Pendaftaran Merek Kolektif terhadap Pedagang Keripik di Kawasan Sentra Industri Sentra Industri Keripik Kota Bandar Lampung”, Skripsi Fakultas Hukum Universitas Lampung, h. 31. 
hak ataupun menggugat pihak lain yang tanpa izin menggunakan mereknya. ${ }^{17}$

Agar dapat memperoleh hak atas merek, pendaftaran atas merek tersebut merupakan suatu keharusan. Negara tidak akan memberikan perlindungan pada merek yang tidak didaftarkan, sehingga apabila ada pihak lain yang meniru merek tersebut, pemilik merek tidak memiliki perlindungan hukum. 18 "Hal ini berarti tanpa mendaftarkan merek, seseorang tidak akan diberikan perlindungan hukum oleh negara apabila mereknya ditiru oleh orang lain." 19

Perlindungan hukum dalam kekayaan intelektual merupaka pemberian penghargaan atas materi yang telah dikeluarkan kepada setiap pencipta, yang merupakan suatu keadilan karena dia telah mengorbankan tenaga, waktu, serta pikirannya untuk menghasilkan karya tersebut, dimana karya tersebut adalah karya orisinil. ${ }^{20}$ Tidak diberikannya perlindungan hukum oleh negara akan menyebabkan ketidakadilan atas kerja keras yang telah dilakukan oleh seorang yang telah menghasilkan suatu kekayaan intelektual.

Suara sebagai merek wajib didaftarkan sesuai dengan ketentuan perundang - undangan merek di Indonesia. Pendaftaran suara sebagai merek merupakan bentuk perlindungan hukum oleh negara kepada pemilik merek. Akibat hukum suatu suara tidak didaftarkan adalah tidak diberikannya perlindungan hukum oleh negara pada pemilik merek suara, konsekuensinya apabila tanda

17 Supramono, G. 2008 Menyelesaikan Sengketa Merek menurut Hukum Indonesia, Rineka Cipta, Jakarta, h. 16.

${ }^{18}$ I Made Deno Kardika Putra, I Wayan Wiryawan, 2016, "Pendaftaran Merek", Jurnal Fakultas Hukum Universitas Udayana, h.2.

19 Astarini, D.R.S. 2009 Penghapusan Merek Terdaftar, PT Alumni, Bandung, h. 47.

${ }^{20}$ Dharmawan, N.K.S, 2014, Relevansi Hak Kekayaan Intelektual Dengan Hak Asasi Manusia Generasi Kedua. Jurnal Dinamika Hukum, h. 524. 
suara tersebut digunakan atau ditiru oleh orang lain tanpa izin pemilik merek suara, pemilik merek tersebut akan kesulitan melakukan upaya hukum untuk mempertahankan tanda suara miliknya karena tanda suara tersebut tidak dilindungi oleh negara sebagai merek.

\section{PENUTUP}

\subsection{Kesimpulan}

Dari hasil penelitian diatas dapat ditarik kesimpulan sebagai berikut:

1. Pendaftaran Suara berdasarkan ketentuan udang - undang merek dapat dilakukan dengan memenuhi persyaratan pendaftaran merek di Direktorat Jendral Kekayaan Intelektual, dimana khusus untuk pendaftaran suara harus dapat dipresentasikan secara grafis dengan melampirkan notasi dan rekaman suara.

2. Akibat hukum suatu suara tidak didaftarkan sebagai merek adalah negara tidak akan memberikan hak atas merek pada pemilik merek suara. Maka negara dalam hal ini tidak memberikan perlindungan apabila suara tersebut digunakan atau ditiru oleh orang lain.

\subsection{Saran}

Pendaftaran suara sebagai merek merupakan hal yang masih baru bagi pengusaha - pengusaha Indonesia, mempresentasikan suara secara grafis sesuai dengan ketentuan perundang - undangan masih menimbulkan kebingungan di tengah masyarakat, untuk itu pemerintah di harapkan mampu mensosialisasikan mengenai tanda pembeda baru berupa suara yang di daftarkan sebagai merek demi meninjang persaingan usaha dewasa ini yang mengedepankan persaingan merek produk. 


\section{DAFTAR PUSTAKA}

\section{Buku}

Astarini, Dwi Rezki Sri, 2009, Penghapusan Merek Terdaftar, PT Alumni, Bandung.

Dharmawan, N.K.S., 2016, Hak Kekayaan Intelektual (HKI), Deepublish, Yogyakarta.

Fermansyah, Heri, 2018, Perlindungan Hukum Terhadap Merek: Panduan Memahami Dasar Hukum Penggunaan dan Perlindungan Merek, Medpress, Yogyakarta.

Jened, R., 2015, Hukum Merek (Trademark Law) dalam Era Gobalisasi dan Integrasi Ekonomi, Prenadamedia Group, Jakarta.

Miru, Ahmadi, 2005, Hukum Merek: Cara Mudah Mempelajari Undang - Undang Merek, PT RajaGrafindo Persada, Jakarta.

Munzir, Ibnu, dan Kadarudin, 2014, Perlindungan Hak Kekayaan Intelektual Terhadap Produk Indikasi Asal, Pustaka Pena Press, Makassar,

Sarjono, A., 2010, Hak Kekayaan Intelektual \& Pengetahuan Tradisional, P.T. ALUMNI, Bandung.

Sulistyowati, 2009, Metode Penelitian Hukum: Konsilassi dan Refleksi, Yayasan Pustaka Obor Indonesia, Jakarta.

Supramono, G., 2008, Menyelesaikan Sengketa Merek menurut Hukum Indonesia, Rineka Cipta, Jakarta.

Utomo, T. S., 2010, Hak Kekayaan Intelektual (HKI) di Era Global Sebuah Kajian Kontemporer, Graha Ilmu, Yogyakarta.

\section{Jurnal dan Skripsi}

Alif Kartika Irianti, et. Al., 2015, "Perlindungan Hukum bagi Merek 3 Dimensi Menurut Undang - Undang No.15 Tahun 2001 tentang Merek", Jurnal Hukum Universitas Brawijaya.

Dharmawan, N.K.S, 2011, Perlindungan Hukum Atas Karya Cipta Program Komputer di Indonesia (Studi Perbandingan dengan Negara Maju dan Negara Berkembang), Masalah Masalah Hukum.

Dharmawan, N.K.S, 2014, Relevansi Hak Kekayaan Intelektual Dengan Hak Asasi Manusia Generasi Kedua. Jurnal Dinamika Hukum. 
Elizabeth Megatri, 2018, "Potensi Pendaftaran Merek Kolektif terhadap Pedagang Keripik di Kawasan Sentra Industri Sentra Industri Keripik Kota Bandar Lampung", Skripsi Fakultas Hukum Universitas Lampung.

Putra, I Made Deno Kardika, I Wayan Wiryawan, 2016, "Pendaftaran Merek", Jurnal Fakultas Hukum Universitas Udayana.

Krisna, Putu Eka, Dewa Gde Rudy, 2018, "Perlindungan Hukum terhadap Hak Merek Terkenal di Indonesia", Jurnal Fakultas Hukum Universitas Udayana

\section{Internet}

WIPO, 2009, Smell, Sound and Taste - Getting Sence of NonTraditional Marks, Serial Online Febuary, URL: https:// www.wipo.int/wipo_magazine /en/2009/1/article_0003.html, diakses pada 25 Febuari 2019.

\section{Peraturan Perundang-Undangan}

Undang - Undang Nomor 20 Tahun 2016 tentang Merek dimuat dalam Lembaran Negara Republik Indonesia Tahun 2016 Nomor 252 